\title{
Wilfrid Laurier University Press
}

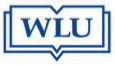

Dear Author,

Please print out the enclosed electronic proofs, read carefully, and return them to the address below within three days of receiving them. Delay in returning them may mean that necessary corrections will not be made. Please keep in mind the following:

- Where word divisions occur at the end of a line, please check the hyphenation. The machine we use at this stage in the production of the proofs has a limited vocabulary of hyphenations, and errors do occur.

- Changes on the proofs should be limited to corrections of typographical errors made by the editors or the typesetters working from your edited manuscript. If you wish to request excessive further changes, or to revise, at this stage, please enclose a check made out to the Canadian Corporation for Studies in Religion to cover the cost of these changes. The rate is \$2.75 per line.

- Please mark your corrections clearly.

- Note that there may be queries that appear either in the margin or at the end of the notes.

Return corrections to:

Aaron W. Hughes, Managing Editor

Studies in Religion / Sciences religieuses

Department of Religious Studies

University of Calgary

2500 University Dr. NW

Calgary, AB T2N 1N4

CANADA

If you have only minor changes, they can be emailed to Aaron at: hughesa@.ucalgary.ca (please note the "a” before the @).

Please let me know that you've received this e-mail and attachment. If you have any problems with the file, please let us know.

Thanks!

Pam Woodland

WLU Press

519-884-0710, ext. 2149

pam@press.wlu.ca 


\title{
Temperance, temples and colonies: Reading the Book of Haggai in Saskatoon
}

\section{Christine MitGhell}

\begin{abstract}
Summary: In this paper, I situate myself as a reader reading from the former temperance colony of Saskatoon. Taking as my starting point John Kessler's heuristic device of a Persian-period "charter group" (2006), I ask how my situation in Saskatoon affects how I read the book of Haggai, and how my reading of Haggai affects my understanding of Saskatoon. I conclude with some remarks on the possibility of examining my readings typologically; that is, seeing my readings as "types" for Canadian scholars abroad and in Canada studying the texts and text-worlds of Persian-period Yehud.

Résumé : Dans cet article, je me situe comme lecteur provenant de l'ancienne colonie de tempérance de Saskatoon. M'inspirant du dispositif heuristique de charter group que John Kessler (2006) applique à la période perse, je me demande comment mon contexte affecte ma lecture du livre d'Aggée, et comment cette lecture d'Aggée affecte ma compréhension de Saskatoon. Je conclus par quelques remarques sur la possibilité d'examiner mes lectures comme une typologie, c'est-àdire en considérant mes lectures comme des «types » pour les spécialistes canadien(ne)s, à l'étranger et au Canada, qui étudient les textes et les mondes-du-texte du Yehud de la période perse.
\end{abstract}

\section{Introduction}

In June of 2002, I moved from Ontario to Saskatoon to take up my current position. The first time I had been to Saskatoon or Saskatchewan in my life was for the interview, a few months before my move. However, my family and I have always been local history buffs, and summer holidays have tradi-

Christine Mitchell is Professor of Hebrew Scriptures, St. Andrew's College, Saskatoon, SK S7N 0W3; e-mail: christine.mitchell@ usask.ca. The author wishes to thank the Local History Room of the Saskatoon Public Library and the Special Collections Department of the University of Saskatchewan Library for assistance in locating materials for this article, as well as John Kessler for providing me with a pre-publication copy of "Persia's Loyal Yahwists" (2006), and for his encouragement generally.

Studies in Religion / Sciences Religieuses 36/2 (2007): 261-277

๑ 2007 Canadian Corporation for Studies in Religion / Corporation Canadienne des Sciences Religieuses 
tionally consisted of innumerable local museums, provincial heritage plaques, and national historic sites. We also read a lot of history books. So soon we were accumulating a small collection of books on Saskatoon and Saskatchewan and discovering that there is more to the history of the area than the railway, the Riel Rebellion and Ukrainian immigration (staples of 1970s and 80s Ontario history curricula).

Towards the end of that first year, the Canadian Society of Biblical Studies (CSBS) was meeting in Halifax, and one of the papers read there was John Kessler's "Persia's Loyal Yahwists" (2006), to which I will return below. I enjoyed the paper-and kept the extensive handout outline. But it was not until the following fall that I saw why this paper was so intriguing to me. Picture the scene: I am standing in a large classroom, with about 25 desks pulled into a large circle. I am actually standing in the middle of the circle. It is the compulsory "Introduction to Hebrew Bible" class of my college. We are talking about Ezra-Nehemiah, and I am raising the main points of Kessler's argument and setting it in contrast with the models of Blenkinsopp and Weinberg (on which more below). And then I had an epiphany, right in the middle of that circle. I pointed out the window: "Over there, just across the street, is what's left of the Temperance Colony that founded Saskatoon. The sort of thing we're talking about in Yehud also happened here." No one else in the classroom got quite as interested in my insight as I was, but that did not matter. It was at that moment that this paper was conceived.

In this paper I will briefly discuss Saskatoon and the temperance colony, highlighting aspects of the history and social context that I find suggestive. Then I will move on to a reading of Haggai informed by this intertext. Why do I term the Saskatoon discussion an intertext? Because when I write down the history of the Temperance Colony, I create a text, a story, a narrative, that cannot but be influenced by the purposes for which I wrote it (cf. White 1978 ; 1973). ${ }^{1}$ A hermeneutical circle it may be to then use my Haggai-influenced narrative of Saskatoon to analyze my reading of Haggai, but it is a self-conscious one (cf. Gadamer 1989: 267, 293-95). When I do my close reading of Haggai, I know I am reading it in light of this Saskatoon context and narrative history. In the end, however, I see my reading not so much as contributing to the scholarship on Haggai, as a typological reading for a certain kind of work in biblical studies (specifically the resurgence of interest in the Persian period), in which Canadian scholars are disproportionately represented.

\section{The "Charter group"}

One of the more interesting and difficult questions about the Persian period in Yehud has to do with the socio-political organization of the community. Any model that purports to describe the organization of the community in Yehud has very little other than the biblical texts to draw upon. There is little extra-biblical written evidence to help understand Yehud in the Persian 
period, although there is some comparative material available, and it is possible to extrapolate from the material that describes the situation elsewhere in the Persian empire (Grabbe 2004: 142). In my discussion here, readers should be aware that I am not, primarily, either a historian or a sociologist of this period. However, the social dynamics described are a part of the intertext that I am constructing.

Since the work of Joel Weinberg, who proposed a model of the CitizenTemple Community (the collected essays are in Weinberg [1992]), much of the scholarship on the period has either worked with the model, refined it, or reacted against it. Weinberg proposed a model for understanding Persian-period social organization whereby the community organized itself around the Jerusalem temple. The temple was not the land-owner (as in the comparable temple-based communities of the ancient Near East), but the members of the community owed loyalty to the temple. They were organized into a collection of bet-abot, or ancestral houses, and it was the bet-abot that collectively owned the land.

There are a number of problems with this model, which have been discussed by a number of scholars (Bedford 1991: 155-59; C. Carter 1999: $297-$ 307; cf. Grabbe 2004: 144-45; Williamson 1998), and we might consider that these objections also hold for any refinements of the model. ${ }^{2}$ Of great importance is the discussion and refinement of the proposal by Joseph Blenkinsopp (1991). Blenkinsopp proposed a variation of the model, suggesting that the power of the community was not lodged in the collection of bet-abot, but rather in the qahal, or assembly. The qahal was a model of communal governance imported from the exilic community, and seems to have only included the members of the golah or the returned exiles. Of course, Blenkinsopp's proposal has itself been the subject of a number of criticisms. However, the basic model seems to be the most widely accepted one at this point (cf. Grabbe 2004: 144-45).

It is in this context that we must understand Kessler's proposal of a Persian-period "Charter group" (2006). Kessler uses the work of John Porter (1965), widely hailed as the founder of Canadian sociology (cf. the essays in Helmes-Hayes and Curtis 1998), in order to propose (as a heuristic device) that we understand the post-exilic community in Jerusalem/Yehud as a "Charter group." Kessler is right to point out that for Porter, the focus of attention was not on developing a theory of the Charter group. Kessler also summarizes Porter's contribution well. What is interesting, however, is Kessler's own synthesis of a qahal-type community (pace Blenkinsopp) with the ideas of Porter. In essence, Kessler reconceptualizes the qahal as a Charter group. This is a distinct improvement on the model of the qahal, as it allows the power dynamics to be more clearly visible (power being one of Porter's primary concerns, as Kessler notes; cf. Clement 1998).

However, there are several differences between the way the Porter conceptualized the Charter Group and the way that Kessler appropriates it for 
his study. Kessler points out some of these himself (e.g., the Yehud group being re-settlers). The Charter group, in Porter's conception, was the socially dominant and originary group, able to set the standards and agenda for the entire society. If we were to apply this model more strictly to the Persian period, it would be the Babylonian community that would have seen itself as the Charter group (as, for example, in Ezekiel). The Yehud-based Babylonian elite group would only have become a Charter group once well enough established in the community to become socially dominant.

\section{Saskatoon and the temperance colony}

Saskatoon is the only community in Canada that was founded specifically as a temperance colony. In 1881, J. A. Livingston and John Lake founded a Temperance Colonization Society (TCS) in Toronto with the goal of setting up a colony in the Northwest Territories (present day Saskatchewan makes up a part of that territory) that would be alcohol-free (HAS 1927: 15). The TCS was structured not only as a club or society, but also as a speculation (TCS 1882). By April 1882, the TCS was incorporated, and had been granted 213,000 acres around the South Saskatchewan River as part of the federal scheme to settle the West and both justify and fund the transcontinental railway. The TCS had actually requested over 2 million acres, but even as it was, the TCS received the largest land grant of any of the various colonization societies that had been set up (Lalonde 1969: 29-30,63).

It is, of course, no coincidence that Treaty 6 had been concluded in 1876, which left open an "empty land" across what is now central Alberta and Saskatchewan for the Euro-American settlers (Taylor 1985). The 1870s marked the transition to colonialization in the Canadian West (S. Carter 1999: 112). The First Nations peoples were being removed to reserves, one of which was immediately south of the TCS land grant, although these peoples did not see land ceding as part of the treaties, but rather peaceful relations (S. Carter 1999: 124-25). I note this because although Haggai does not construct Yehud as an empty land, other biblical texts (e.g. 2 Chron. 36:21) do make this connection, and many of the sociological models described above work with this Persian-period ideological framework.

In 1882, John Lake was elected by the TCS as its commissioner, entrusted with the task of going out to the area, making an inspection of the land grant, and deciding on the location of the town site. At this time, the railway only went as far west as Moose Jaw, and it was a $225 \mathrm{~km}$ overland trek up the trail, which meant days travelling on foot or horseback; a considerable effort was involved. Legend has it that the new town site was named Saskatoon by Lake on account of the local Cree name for the berries that grew around the countryside, but the exact details of the naming event are now obscure, mainly because Lake changed his story over the years (cf. HAS 1927: 10 n.3, 16). Soon the government surveyors were out in full force, laying out the 
farm lots and the town site plan. At first, the surveyors were dividing up the land into narrow river-fronted strips as in Quebec and along the Red River in Manitoba. Lake put an end to this, not by trying to persuade the local overseer of the surveyors, but by going to Ottawa and talking to the Surveyor-General and the Minister of the Interior, who happened also at that moment to be the Prime Minister, Sir John A. MacDonald. The land was then laid out in square sections. In Lake's memoir, his access to such high-ranking officials is taken for granted (HAS 1927: 16-17), although the considerable effort to get from Saskatoon back to the railroad is glossed over.

In 1883, the TCS put out a pamphlet to encourage settlers to come to the colony, with an illustration "View of a North West City" (fig. 1). The blessing that would come from a temperance colony was clear: "A project which aims at proving that the highest attainable degree of happiness and prosperity are compatible with, and promoted by freedom from 'the manufacture, importation, and sale of strong drink'” (Telfer 1884). In 1883, settlers began to arrive, some of them as squatters. We need to keep in mind that the TCS was not just a society concerned with moral issues; it was also an economic entity, trying to make money for its principal directors-and they needed to get settlers out there to purchase land from the society, as the more settlers there were, the less the TCS would have to pay the government for the land (Lalonde 1969:44)! The survey of the town site on the east side of the river was completed by the end of the summer, and there were 30 or 40 settlers living there, none of them in an actual house (HAS 1927: 17). But by the end of the next summer, 1884, a government inspector could declare that there were "several handsome and substantial buildings-school house, hotel, stores, private residences, etc...." and that there were 80 settlers (quoted in Kerr and Hanson 1982: 10). Earlier in that same summer, a new arrival had seen it differently: "They called it the City of Saskatoon, but when we arrived there were seven houses and not one properly finished. People had told me not to go but I thought that since it was called a city, it must be a good sized place" (quoted in Kerr and Hanson 1982: 10). However, the earliest illustration of Saskatoon, from 1885, demonstrates that there was a considerable difference between what actually existed on the ground and what settlers were being sold (fig. 2). Legend has it that this is why the first sawmill in the town site was built-even though it took an enormous amount of time just to find enough trees that could be sawn to make the roof for the mill; the TCS had advertised that a mill was on the site, and they were afraid of the lawsuits that might follow if there was no mill (HAS 1927: 45).

There were two significant problems that the TCS had in those early years. The first had to do with the Temperance ideal itself. The TCS (most of whose directors never set foot in Saskatoon) wanted to insist that all settlers sign a pledge to refrain from the sale of alcohol, or forfeit their land. Although the settlers were all believers in the Temperance ideal, they did not want to do this, and passed a motion on July 16, 1884 against "the usurpation 


\section{Figure 1}

"View of a North West City" (1883)

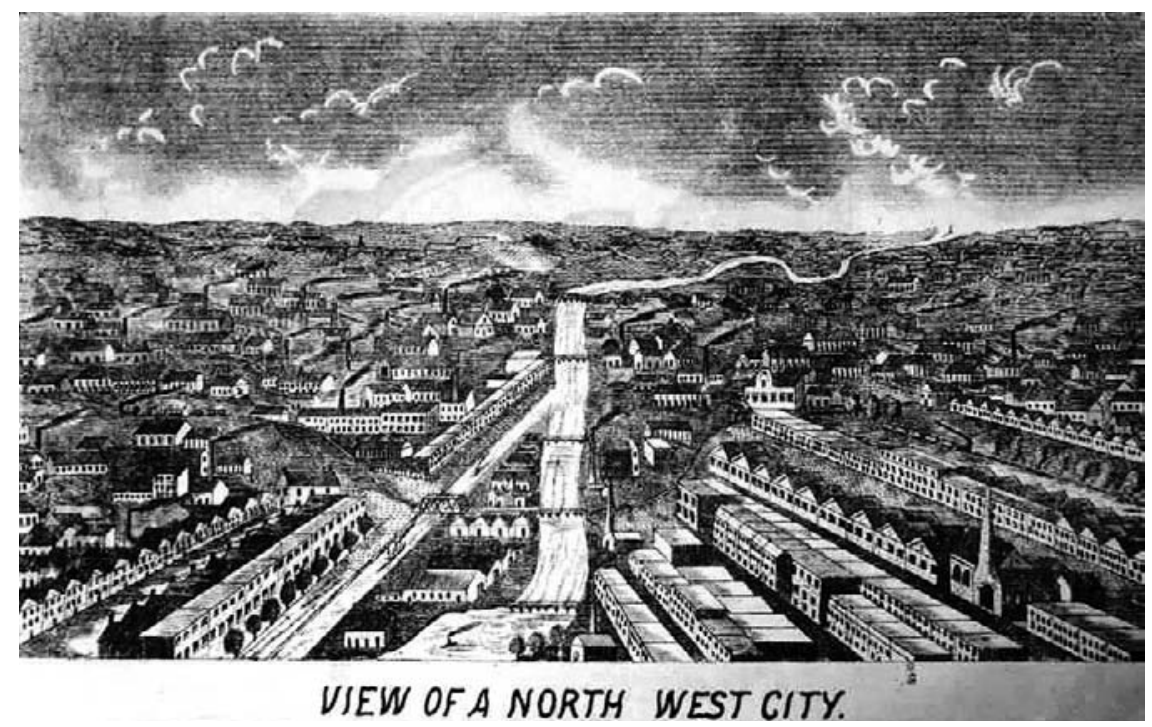

Courtesy of Saskatoon Public Library-Local History Room, item number LH5115a.

of power by the Temperance Colonization Society" (quoted in Kerr and Hanson 1982: 10). A related problem had to do with the assignment of lots in the colony. Although the TCS thought it had exclusive rights to the entire land grant, the government inspector on his visit in August 1884 made it clear that the TCS only had control of every second lot (like a checkerboard), and that the rest of the lots had to be sold to whomever could pay the price as a homesteader (Lalonde 1969: 120-22). Clearly this would be a problem if one were trying to set up a temperance colony-when even the prohibitionists had already resisted having to sign a pledge against the sale of alcohol, and in fact the TCS continued in the practice in order to keep the support of its prohibitionist investors (Lalonde 1969: 122). The Christmas 1903 Illustrated Supplement of the Saskatoon Phoenix notes that this issue led to many difficulties "which to this day [1903], have not been overcome" (reprinted in HAS 1927: 9). Presumably there was still (in 1903) desire for prohibition at least in some quarters. In 1899, a liquor license was granted to an establishment in the (now former) TCS town site, but by the next year the bar had been closed by efforts of the temperance forces (Kerr and Hanson 1982: 25). One of my students informed me that until recent times the east side of the river was known locally as the "dry side"; although research suggests that this was not due entirely to prohibitionist fervor, but rather to the fact that Saskatchewan liquor licensing laws until 1960 did not allow licensed estab- 


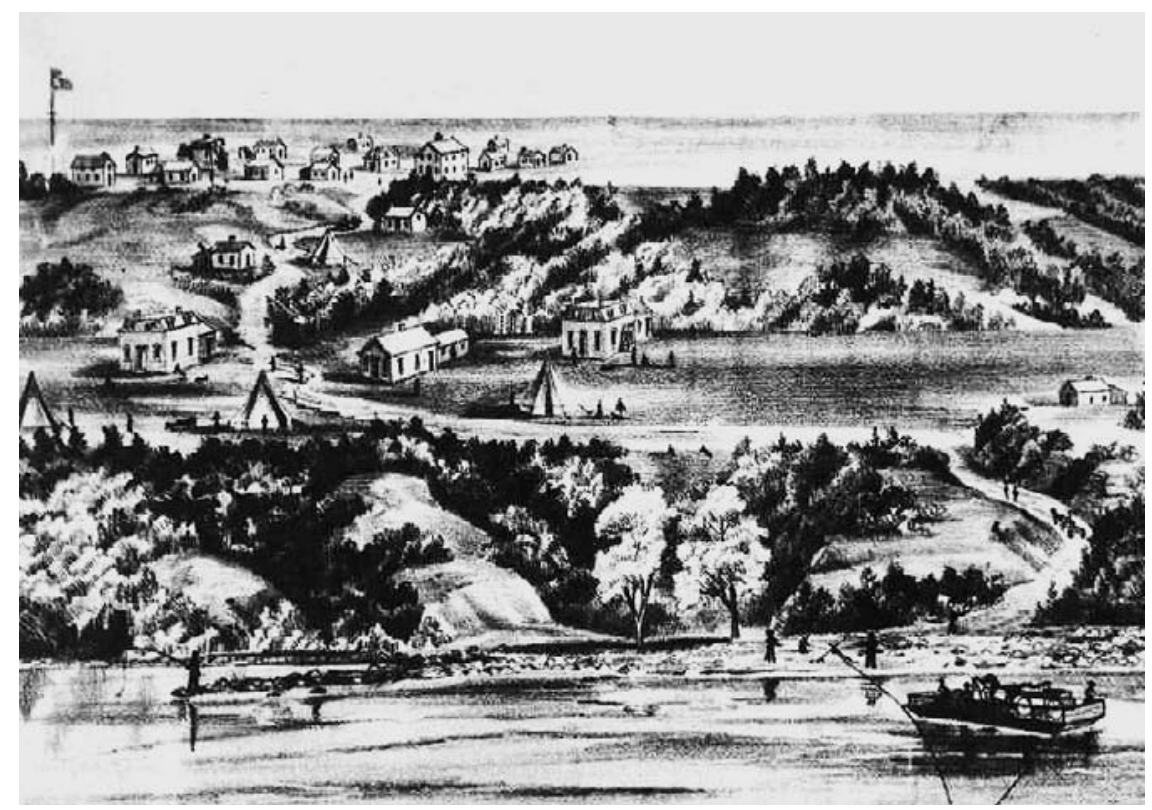

Courtesy of Saskatoon Public Library-Local History Room, item number LH1587.

lishments except in large hotels-and there was only one hotel on the east side of the river (Mushka 1980).

The second significant problem the TCS faced was financial. Although the people who bought scrip for the colony were supposed to either settle themselves or by substitute, and although some of the early settlers were among the founders of the TCS or early scrip-holders, in fact, many of the controlling interests of the TCS were living in Ontario. Their interest was in the Temperance ideal, to be sure, but it was also in making money on their government contract to settle the West. But there were a number of problems. There were over fifty lawsuits against the TCS, first beginning in 1884, largely involving the claim that the TCS was selling land it did not control, namely the homestead lands on the alternating lots. John Lake, who had found the site and helped found the TCS, ended up paying $\$ 8000$ in what he termed "the wreck," and left the TCS in 1885 (HAS 1927: 17); although he founded the city, he never lived in it permanently. But the bigger financial wreck was the one that took place entirely in Ontario. It began with the directors selling land to themselves below cost and then flipping it on the open market, in theory tripling their investment value (at least), but without any money changing hands, as it was all done on promissory notes. It was, in essence, a 
pyramid scheme, set up by the federal government in the hope that both the money raised from the various colonization societies for the land grants would pay for the transcontinental railway, and the companies would ensure the settlement of the West (Lalonde 1969: 29-30). The TCS was the next group down the pyramid. It might have all worked out if there had been huge waves of settlement in the west. But there was an economic downturn in 1883-84, and the Riel Rebellion of 1885, which generated erroneous headlines like "The Saskatoon Settlement Plundered" (Manitoba Daily Free Press 1885; Turner 1982: 7), finished the job (Kerr and Hanson 1982: 19). Most colonization companies stopped trying to colonize after 1885, and focussed on recovering their investment. Only the TCS continued, but got only ten settlers from 1886-1891 (Lalonde 1969: 167).

To make a long and complex story short and simple, the TCS fell apart, first with a court deciding in 1886 that the original directors should be removed. Although the TCS had paid $\$ 84,000$ to the government in 1882 , they had raised an additional $\$ 217,000$ that had simply vanished, in one court's judgment delivered on March 24, 1886, into the pockets of the original directors (The Globe 1886). The government started negotiations to end the contract in 1886, and released most other companies from their obligations in 1887, but the TCS insisted that temperance or prohibition be written into the final agreements with settlers, to which the government would not agree. The plethora of lawsuits led to a postponement of negotiations. In 1891, under pressure from the scrip and share holders, and with the lawsuits out of the way, the government cancelled its contract with the TCS-which was the only colonization company to last that long, and only because it was so legally entangled (Lalonde 1969: 226, 167, 201)!

Although it was strong Methodist forces that led to the Saskatoon temperance colony, and by the end of the first few years there were places of business, a school, and an agricultural fair, there was no church in the town site. Worship services were held in people's homes, barns or stables, or in the school after it was built. The TCS had sold a lot in the town site to John Lake in trust for a Methodist church in 1884. But it was not until 1886 that members began to work on building some kind of church structure, and in fact lumber was pledged (Grace United Church 1951: 3). What was actually of more concern to the community was the lack of a minister, as expressed in an 1887 letter to the superintendent of missions in Winnipeg for the Methodist Church: "When the T.C.S. was first formed, there were a number of Methodist ministers connected with it, and we were given to understand that as soon as practicable a Methodist minister would be sent to the colony. We came here expecting that that would be the case" (quoted in Grace United Church 1951: 4). Finally, in the spring of 1892, when the village was fairly secure, the church board approved the building of a church structure on the lot. It was dedicated on January 15, 1893. However, it did not receive a name until 1910, when it was named Grace Methodist Church, in honour of Grace Fletcher, 
a settler of 1885 . In that same year, construction began on a new brick building, and Methodist (later United Church) congregations have been using that site ever since (Lepp 1985).

A final point is of interest here. The site on the east bank of the South Saskatchewan River had been known as Saskatoon since its founding. However, settlements were also growing up on the west side of the river, primarily due to the construction of the railway on that side in 1890 . Those west side settlements grew more quickly through the 1890s, and one of them (the location of the modern downtown Saskatoon) was incorporated as a village in 1901, with the name "Saskatoon." This must have been felt as the final insult to the original colony. The town site on the east bank chose "Nutana" as its new name. It was in 1906 that Saskatoon, Nutana and Riversdale (on the west bank) amalgamated to form the City of Saskatoon (population 3,011). The west side continued on to be the commercial centre of the city (Kerr and Hanson 1982: 35-36).

\section{Haggai}

In certain ways, we can read the book of Haggai as a record of the Saskatoon temperance colony-in other words, we can read it intertextually with the narrative I have constructed above. Others might term this Saskatoon narrative as a heuristic device to open up the reading of Haggai, but I would argue that since my construction of the Saskatoon narrative is intertextually related to Haggai, they are both part of a mutually influencing intertextual web (or hermeneutical circle, if you like).

First, Haggai is the conduit between YHWH Sebaoth and Zerubbabel the governor of Yehud and Joshua the high priest (1:1). The leaders are appealed to-but I think the Saskatoon narrative legitimately allows us to raise the question of where the leaders were physically located for Haggai's implied audience. What kind of roles might these characters in the text have envisaged for themselves? How is it possible to have a high priest without a temple at which to preside? (And, parenthetically, what kind of worship is Haggai presuming to be going on without a temple in Jerusalem?) And where precisely is "Haggai" writing from himself? The traditional placement of Haggai has been as an indigenous prophet, one of the people of the land, as it were, who was calling out for a restoration of the Jerusalem temple (e.g., Bedford 2001: 273). ${ }^{3}$ My Saskatoon narrative makes me think otherwise. Granted that a 19th-century Methodist theology of ministry is most likely significantly different from a 6 th or 5 th century B.C.E. theology of priesthood, but the heuristic device of the charter group would lead us to the conclusion that the implied author Haggai was a member of that elite group from outside the land. As well, the people on the ground in Saskatoon, as it were, were not calling out for a church building to be started, even when lumber was offered!

There is a striking phrase in Lepp's article on Saskatoon's first church: 
"By the fall of 1886 it was felt that the time had come for establishing a regular church" (1985: 15, emphasis mine). How does YHWH quote the people in Haggai 1:2? "This people say, 'The time has not come-the time for the house of YHWH to be (re)built" (emphasis mine). The "time" would have been the "appointed time" (Kronholm 2001: 447). I tend to agree with those who favour a non-eschatological interpretation for 'ét (time) (e.g. Bedford 2001: 270-73; Kessler 1998; Kronholm 2001: 449-50). But even when the people agree that the time has come (in 1886), church construction was still not begun for another six years! How much greater would Haggai's "people" see the difficulties if they do not think the time has come? It is not surprising, therefore, that Haggai's rhetoric lifts up the issue of "time" in 1:4: "Has the time come for you to live in your paneled/covered houses, when this house is desolate?" Again, I see an interesting parallel to our other narrative, namely that there were reasonably substantial houses on the Saskatoon town site long before the church was built, but before living in their covered or paneled houses, people had been living in tents or in sod-roofed dugout houses. Once people had the more substantial houses, then they could think about it being "time" to build a church. Bedford suggests that the building of the Temple was not the primary reason for the return to Yehud from the golah: that this was a new task set to them by (among others) Haggai (2001: 272-73; contra Petersen 1991: 135).

Haggai 1:5-6 is interesting: the people are exhorted to "set your minds/ hearts on your ways," that is, "think about what you're doing." They have little food (due to small harvests), yet they eat, drink, clothe themselves, and their money runs through their fingers-they are not spending the few resources they have wisely. This leads me to wonder, what are the community's priorities? Clearly, staying alive would be one, yet Haggai claims that they have poor resources because (?) they have no temple. In the Saskatoon narrative, certainly staying alive was a high priority, and it was tough; so the colonists using food, drink, clothing and material resources for themselves was crucial for their survival. As John Lake said about the settlers of the first winter, "God and the people alone know how they pulled through" (HAS 1927: 17). ${ }^{4}$ Were other motivations such as the temperance ideal or even the offer of cheap land at all relevant? One early settler later recalled, "I came ... because I wanted to see the country. I had no intention of staying, but I could not get my money from the Temperance Colonization Society so I had to stop two or three months and by that time I began to like the place..." (HAS 1927: 46). People drifted in and out of Saskatoon, and there really was nothing to unify them except staying alive: the Temperance ideal did not unite them. Perhaps Haggai's implied audience did not see the Temple as a unifying feature either.

It is not clear from the text of Haggai itself who the people $\left(h \bar{a}^{\circ} \bar{a} m\right)$ are. In 1:12, 14 and 2:2 they are called (kol-) 'se' $\bar{e} r \hat{\imath} t h \bar{a}^{\prime} \bar{a} m$ (the [whole] remnant of the people); in 2:4 they are called kol 'am hàa'ares (all the people of the land). 
Kessler's nuanced discussion of the terminology suggests that the use of $s^{e}$ 'érit (remnant) is meant to emphasize that the whole community has become the obedient remnant after having been delivered (2002: 141-42; contra Clines 1994: 82-83). This is interesting. One of the strengths of Kessler's discussion of $h \bar{a}^{\natural} \bar{a} m$ is that he does not insist that $h \bar{a}^{‘} \bar{a} m$ was a golah community (i.e., exclusively from Babylon). He leaves that possibility open, but relegates it to a footnote (2002: 142 n. 270). It therefore follows logically in his argument that kol 'am $h \bar{a}$ 'âres in 2:4 would refer to this entire "delivered" group, rather than being used polemically as in Ezra (2002: 168-69); we might compare Floyd's point that kol 'am hā'âres is the community, rather than the opponents of the community as in Ezra (2000: 281; cf. Bedford 2001: 274-76). The Saskatoon narrative would suggest something slightly different: that the people are unified not by theological aims (Methodist temperance), but by economic ones-people were looking for a better life. It is because of this search for a better life that so many were disappointed with the actual conditions in Saskatoon when they arrived. But for many there was no going back. While John Lake's account of himself has him zipping hither and yon, for most of the new settlers, going back anywhere was not an option. They were not delivered: they were exiled. Is that how the implied audience of Haggai saw themselves? And how did the Ontario TCS sponsors see the Saskatoon settlers? Were they seen as a "remnant," faithful or otherwise? Or were they seen as causing more trouble than they were worth? They certainly generated a lot of lawsuits.

In Haggai, the community is exhorted to build a Temple, while in Saskatoon, the community was exhorted to build up Temperance-the correct parallel is not between Temple and church, but between Temple and Temperance: Temperance is what would be likely to bring blessing, as Haggai suggests the Temple would (1:7-11). But does that mean, bringing Haggai to bear on Saskatoon, that those early settlers did not bring their full energies to the temperance ideal? Perhaps the refusal to sign the pledge might be seen as a symptom of this. In that case, maybe we can turn the circle back on Haggai and ask again, where does the impetus for Temple building come from? From those on the ground, or from those in Babylon (Toronto) who want to see a certain goal achieved?

When we turn to Haggai 2, one of the first passages of interest is vv. 3-4, "Who among you are left who saw this house in its former glory? How do you see it now? Is it not as nothing in your sight?" (see fig. 2 again). It is hard to believe that there were very many in Haggai's implied audience who were at least 70 years old and could actually remember the Solomonic Temple. But is what we are talking about here not an actual Temple but the Temple as ideological construct? Remember the pamphlets that were used to sell Saskatoon to potential settlers, and how disappointed those settlers were when they arrived. So is the bèt-yhwh $s^{e} b \bar{a}, \hat{o} t$ (House of YHWH of Hosts) that Haggai is talking about, the former $b \bar{e} t-y h w h$ (House of YHWH) or hēkal-yhwh (Temple 
of YHWH) now constructed in the mind-perhaps expressed in some of the Psalms, or even in 1 Kings? What Zerubbabel, Joshua, and the people are then called to do is to construct something that conforms to this construct.

We know in the Saskatoon narrative that the first grand vision or construct never came to pass: Saskatoon to this day still does not look like Chicago (fig. 1). But in the Saskatoon narrative that actually does not matter, because the narrative was constantly being reshaped. If the Temperance Colony was not going to work out, the next vision was for Saskatoon to be a "Hub City" for the railroads-all (rail)roads would lead to Saskatoon-this would lead to the perhaps literal shaking of heavens, earth, water and dry land and the wealth of the nations flowing into this city: "This year [1908], Saskatoon is the greatest centre of railway construction in the whole world" (SBT 1908: 18; also SBT 1906; cf. Hag 2:6-8). If one argues with Meyers and Meyers (1987), Petersen (1984), Conrad (1999), and others that Haggai is really the first part of a combined book of Haggai-Zechariah 1-8, then one could see in Zechariah 1-8 some of the reinterpretation and reshaping of the vision.

Turning to the next oracle in Haggai 2:10-19, we can see some interesting possibilities here from our Saskatoon narrative. It seems reasonably clear that in the torah about purity a pure object cannot make other objects (food) pure by physical contact, but that in fact an impure item can transmit its impurity to the pure item. This is, of course, right out of Leviticus and has resonances with Ezekiel. The rhetorical point here is that the people and the land and all its produce is impure and is spreading its contamination. David Clines' point that this in fact paradoxically makes the Temple itself impure is an interesting conclusion to this line of reasoning (1994: 72-76). However, in Haggai, unlike in Ezra-Nehemiah, there is no distinction made between a "pure" golah community and an "impure" remainee community; in this instance the point is that the Temple as envisioned in its construct is needed to remove this impurity. In the Saskatoon narrative, the problem of alternating lots could be seen as an issue of purity: the homestead lots sold to potential non-prohibitionists could contaminate the entire community. If we are seeing temperance and the Temple as analogous in this reading, it is only through temperance that the community could be made pure, and this problem of the lots would make it very difficult. The blessing spoken of in Haggai 2:18-19 comes from the founding of the Temperance Colony itself.

Finally, the last oracle of Haggai focusses on the figure of Zerubbabel. As is well known, Zerubbabel is very prominent in the oracles of Haggai-Zechariah 1-8 and also appears in Ezra, disappearing after Ezra 5:2. It certainly looks like Zerubbabel in Haggai was seen as an important founder: the messianic/Davidic language of Haggai 2:20-23 is well known (e.g., Sweeney 2000: 534); Bedford argues that this was necessary since a monarchic figure was needed to legitimate the temple (2001: 294). But despite Zerubbabel's status in Haggai, this figure disappears abruptly from the biblical texts, although he remains prominent in extra-biblical texts such as Sirach 49:11 
(paired with Joshua in v. 12) and 1 Esdras 3-4, which seems to have been written precisely to play up Zerubbabel (Talshir 1999: 6, 46); Zerubbabel is also much more prominent in 1 Esdras than in its synoptic passages in Ezra. Nevertheless, without claiming any messianic status for John Lake, the Saskatoon narrative is also instructive here. Although John Lake "founded" the TCS and Saskatoon, he became disillusioned with the TCS as it dissolved into lawsuits, and got out; he did not come back to the city until 1904. Here the use of the Charter group heuristic device is especially helpful: the logistical, legal, and financial issues that contributed to the end of the federal government's colonization society experiment also contributed to the end of John Lake's participation: there are reasons why one might choose to disappear from the scene, even if it was something one founded. Perhaps disillusionment is a potential explanation for the disappearance of Zerubbabel.

\section{Biblical studies in Canada-A typological reading}

It should not come as a surprise to Canadian biblicists that there is a large proportion of us working in Persian period texts and contexts. This includes both scholars working in Canada and Canadian scholars working outside of the country. Over the past few years I have asked myself several times why this is so, and have also had a few conversations with others about this topic.

Postcolonial studies on Canada have often noted that Canada is both colonized and colonizer, especially the white English-speaking people in it (others have tended to be more "colonized" and less "colonizer"). 5 As George Elliott Clarke says, "Canada was-is-an assembly of feuding (cultural) nationalisms, (neo) colonialisms, and (economic) imperialisms" (2003: 34, emphasis original). We can see this played out in the Saskatoon narrative: Ontario settlers were sent west, both colonizing land that had belonged to the First Nations, but also being colonized themselves, with the major decisions (especially legal and political ones) being made back in Ontario. At the same time, we should recall that Canada itself was a "Dominion" of the British crown, with such matters as foreign policy under the control of London. Certainly the feeling of being doubly or triply colonized subjects is not one that has disappeared from the Prairie context. Sarah Carter takes issue with this commonly constructed narrative, and suggests that while it is common to see late-19th-century immigrants to the West (like the settlers in Saskatoon) as colonized-"governed by distant and insensitive politicians and administrators"-it is not as common to see the relationship with the First Nations as colonialism, although it continued the pattern from British colonialism in Canada (1999: 102-3). However, while all of this may satisfactorily explain my current interests in the biblical texts of the period of Persian colonization, my interests predate my move here; and there are many other Canadian biblicists not working in the marginalized bits of the country or the continent. I suggest that it is the Canadian's liminal space and context (in between col- 
onizer and colonized; in between historical empires-British and American; both inside the Anglo-American scholarly sphere and also outside it) that leads so many down this road.

However, I think we can explore this also from a meta-level. It is one thing for Canadians (say) to be drawn to a set of texts that explore the issues of colonialism, which I think is true. It is another question entirely to ask about the status of these biblical books within the discipline. These specifically Persian (or early Hellenistic) period books like Haggai have been largely ignored in a great deal of biblical scholarship since Wellhausen, although in many recent articles and books on these texts you will find an almost-obligatory note along the lines of: "Recently the book of X, a long-neglected book, has been the subject of a resurgence of interest." One could (and I do) read this (now) as an example of insecure self-justification. There may be some reasonably clear reasons for this "resurgence" of interest in the Persian period: some of it may be a reaction to the German domination of 19th- and 20thcentury biblical scholarship that denigrated this period and its texts; or similarly a reaction against the Albright-Wright biblical theology movement that also prioritized other texts. But, ultimately, what does it say that Canadians are prominent in a subfield that very few others have colonized? 6

For two decades, the New Testament scholars of the CSBS have worked together in a series of seminars that have, I think, created a distinctively Canadian perspective within that discipline. I do not know if Hebrew Bible scholars will develop a distinctively Canadian body of work (I do hope so), although certainly we do have the resources to do so. What would such a distinctive perspective look like? I think awareness of the margins or awareness of our own in-between-ness might colour our work. What I hope I have shown in this paper is that our reading location does matter, does affect our scholarship, both in terms of interest and perspective. My mutually reinforcing readings of the book of Haggai and the narrative of Saskatoon show how this kind of scholarship might be done. I would like to encourage further readings that explore these texts in our contexts.

\section{Notes}

1 I do realize that the "narrativity" of historiography is a broad topic, much debated by historians, and that there is a great deal more bibliography that I have not cited here.

2 C. Carter argues that Weinberg's hypothesis is neither necessary nor helpful for understanding the period (1999: 307).

3 Petersen suggests that while it looks like Haggai was an indigenous prophet, his personal situation has been left "deliberately enigmatic" (1984: 18-19).

4 Note that he was not actually in Saskatoon himself for the first winter, but had returned to Ontario.

5 There is a lively debate as to whether Canada can be truly classed among the "postcolonial" because of this in-between position. Canadian literature, for example, seems in some ways to be in the same marginal yet not-marginal position as Canadian biblical studies. See Besner (2003), Brydon (2003), Clarke (2003).

6 Israeli scholars are also prominent in Persian-period studies, I think for different reasons. 


\section{References}

Bedford, Peter R.

2001 Temple Restoration in Early Achaemenid Judah. JSJSup 65. Leiden: Brill.

1991 "On Models and texts: A response to Blenkinsopp and Petersen." In Philip R. Davies (ed.), Second Temple Studies, 1. Persian Period, 154-62. JSOTSup 117. Sheffield: Sheffield Academic Press.

Besner, Neil

2003 "What resides in the question, 'Is Canada Postcolonial?'” In Laura Moss (ed.), Is Canada Postcolonial? Unsettling Canadian Literature, 40-48. Waterloo, ON: Wilfrid Laurier University Press.

Blenkinsopp, Joseph

1991 "Temple and society in Achaemenid Judah." In Philip R. Davies (ed.), Second Temple Studies, 1. Persian Period, 22-53. JSOTSup 117. Sheffield: Sheffield Academic Press.

Brydon, Diana

2003 "Canada and Postcolonialism: Questions, inventories, and futures." In Laura Moss (ed.), Is Canada Postcolonial? Unsettling Canadian Literature, 49-77. Waterloo, ON: Wilfrid Laurier University Press.

Carter, Charles

1999 The Emergence of Yehud in the Persian Period: A Social and Demographic Study. JSOTSup 294. Sheffield: Sheffield Academic Press.

Carter, Sarah

1999 Aboriginal People and Colonizers of Western Canada to 1900. Toronto: University of Toronto Press.

Clarke, George Elliott

2003 "What was Canada?” In Laura Moss (ed.), Is Canada Postcolonial? Unsettling Canadian Literature, 27-39. Waterloo, ON: Wilfrid Laurier University Press.

Clement, Wallace

1998 "Power, ethnicity, and class: Reflections thirty years after The Vertical Mosaic." In Rick Helmes-Hayes and James Curtis (eds.), The Vertical Mosaic Revisited, 34-59. Toronto: University of Toronto Press.

Clines, David J. A.

1994 "Haggai's temple, constructed, deconstructed and reconstructed." In Tamara C. Eskenazi and Kent H. Richards (eds.), Second Temple Studies, 2. Temple and Community in the Persian Period, 60-87. JSOTSup 175. Sheffield: Sheffield Academic Press.

Conrad, Edgar W.

1999 Zechariah. Sheffield: Sheffield Academic Press.

Floyd, Michael H.

2000 Minor Prophets, Part 2. FOTL 22. Grand Rapids, MI: Eerdmans.

Gadamer, Hans-Georg

1989 Truth and Method. 2nd rev. ed. New York: Continuum.

The Globe

1886 "The temperance colony: A startling judgment involving nearly $\$ 200,000$."

The Globe, March 25.

Grabbe, Lester L.

2004 A History of the Jews and Judaism in the Second Temple Period, Volume 1. Yehud: A History of the Persian Province of Judah. LSTS 47. London: T. \& T. Clark. 
Grace United Church

1951 Grace United Church Saskatoon 1886-1951. Saskatoon: Modern Press.

Helmes-Hayes, Rick and James Curtis (eds.)

1998 The Vertical Mosaic Revisited. Toronto: University of Toronto Press.

Historical Association of Saskatoon (HAS)

1927 Narratives of Saskatoon 1882-1912, By Men of the City. Saskatoon: University Book Store.

Kerr, Don, and Stan Hanson

1982 Saskatoon: The First Half-Century. Edmonton: NeWest Press.

Kessler, John

1998 "'t (le temps) en Aggée i 2-4: conflit théologique ou 'sagesse mondaine'?" Vetus Testamentum 48: 555-59.

2002 The Book of Haggai: Prophecy and Society in Early Persian Yehud. VTSup 91. 1998: please Leiden: Brill.

2006 "Persia's loyal yahwists: Power, identity and ethnicity in Achaemenid Yehud." marks. In Manfred Oeming and Oded Lipschits (eds.), Judah and the Judeans in the Persian Period. Winona Lake, IN: Eisenbrauns.

Kronholm, T.

2001 "ēt; 'attâ." In G. Johannes Botterweck, Helmer Ringgren and Heinz-Josef Fabry (eds.), Theological Dictionary of the Old Testament, Vol. 11, 434-51. Translated by David E. Green. Grand Rapids: Eerdmans.

Lalonde, André N.

1969 Settlement in the North-West Territories by Colonization Companies, 1881-1891. Unpublished PhD dissertation, Université Laval.

Lepp, Wilbur

1985 "A study of Saskatoon's first church." Saskatoon History 3:15-19.

Manitoba Daily Free Press

1885 "Pitt fallen." Manitoba Daily Free Press, April 21.

Meyers, Carol L., and Eric M. Meyers

1987 Haggai, Zechariah 1-8. Anchor Bible, 25B. Garden City, NY: Doubleday.

Mushka, Chris

1980 "Saskatoon temperance.... Time to dispel old myth about liquor on east side of river." Saskatoon Star-Phoenix, March 1.

Petersen, David L.

1984 Haggai and Zechariah 1-8. Philadelphia: Westminster Press.

1991 “The temple in Persian period prophetic texts." In Philip R. Davies (ed.), Second Temple Studies, 1. Persian Period, 125-44. JSOTSup 117. Sheffield: Sheffield Academic Press.

Porter, John

1965 The Vertical Mosaic: An Analysis of Social Class and Power in Canada. Toronto: University of Toronto Press.

Saskatoon Board of Trade (SBT)

1906 Saskatoon: The Hub of the Hard-Wheat Belt of Western Canada. Saskatoon: Saskatoon Board of Trade.

1908 Saskatoon. Saskatoon: Phoenix Job Print.

Sweeney, Marvin A.

2000 The Twelve Prophets, Vol. 2. Collegeville, MN: Liturgical Press. 
Mitchell / Temperance, temples and colonies

Talshir, Zipora

1999 I Esdras: From Origin to Translation. Atlanta: Society of Biblical Literature.

Taylor, John Leonard

1985 Treaty Research Report: Treaty Six (1876). Ottawa: Indian and Northern Affairs Canada.

Telfer, John H.

1884 Canadian Northwest. Free Homesteads of Wheat and Grazing Land in the Temperance Colony. London: James Iveson.

Temperance Colonization Society (TCS)

1882 Charter and By-Laws of the Temperance Colonization Society. Toronto: Hunter, Rose.

Turner, Adam

1982 Some Rambling Historical Notes and Reminiscences of the Early Days in Saskatoon. Saskatoon: Modern Press.

Weinberg, Joel

1992 The Citizen-Temple Community. Translated by Daniel L. Smith-Christopher. JSOTSup 151. Sheffield: Sheffield Academic Press.

White, Hayden

1973 Metahistory: The Historical Imagination in Nineteenth-Century Europe. Baltimore: Johns Hopkins University Press.

1978 Tropics of Discourse: Essays in Cultural Criticism. Baltimore: Johns Hopkins University Press.

Williamson, H.G. M.

1998 "Judah and the Jews." In Maria Brosius and Amélie Kuhrt (eds.), Achaemenid History XI: Studies in Persian History: Essays in Memory of David M. Lewis, 14563. Leiden: Nederlands Instituut voor het Nabije Ooesten. 
04_mitchell 6/22/07 9:42 Page 278 